\title{
Drilling into Community Perceptions of Coal Seam Gas in Roma,
}

\section{Australia}

\begin{abstract}
Coal Seam Gas (CSG) extraction and its conversion into Liquefied Natural Gas (LNG) for overseas export is a recent phenomenon in Australia. These activities have, not surprisingly, attracted significant attention because of their perceived impacts on the environment and communities. However, community and stakeholder perceptions of these impacts, particularly for local development, have gone virtually unexamined in the literature. This paper aims to bridge this gap by exploring local perceptions of CSG extraction in a rural Australian community. In doing so, the research determines the efficacy of using Social Representation Theory (SRT) and Social Exchange Theory (SET) to assess community perceptions of mining-induced change. Findings reveal that the community perceives CSG extraction to provide positive economic impacts but is concerned about its ability to facilitate long-term economic growth and development. Long-term residents considered regional development to be targeted towards satisfying the needs of mining companies and 'new' migrants to the region. A lack of information about the impacts of CSG extraction has led to heightened apprehension among long-term residents.
\end{abstract}

Keywords: Community, Mining, Impacts, Coal Seam Gas, Liquefied Natural Gas 


\section{Drilling into Community Perceptions of Coal Seam Gas in Roma,}

\section{Australia}

\section{Introduction}

Australia is considerably rich in natural resources and consequently has a lengthy and well documented history of mining (Blainey, 1993; Eklund, 2012; Minifie, Cherastidtham \& Mullerworth, 2013). As one of the world's largest mining countries (Pellegrino \& Lodhia, 2012), mining activity and successive booms have long been the driver of economic development and societal change within Australia (Lawrence \& Davies, 2011; Mercer, de Rijke \& Dressler, 2014), particularly in regional areas (Eklund, 2015; Tomaney, 2010). The most recent mining boom has been no exception, delivering significant economic and societal change (Mercer et al., 2014; Petrova \& Marinova, 2014).

A key driver of this recent mining boom has been the development of several projects aimed at extracting Coal Seam Gas (CSG) and converting it to Liquefied Natural Gas (LNG) for exportation to key international markets (Trigger, Keenan, de Rijke \& Rifkin, 2014). CSG is a naturally occurring methane gas found in coal seams. Extraction of CSG gas can involve the process of fracking to stimulate and accelerate the flow of coal seam gas. Despite procedural variances to CSG extraction and the criticism around the process of fracking, CSG is regarded as a valuable key transition fuel (Connolly \& Orsmond, 2011; Nghiem, Ren, Aziz, Porter \& Regmi, 2011). Demand for CSG is high and forecast to increase, though this is arguable (Chen \& Randall, 2013), as it is viewed as a viable and abundant alternative fuel source to coal (Lin, Zhang, \& Gu, 2010). All the same current demand has seen substantial growth in CSG exploration and extraction in Australia, particularly in regional Queensland (Nghiem et al., 2011). 
The impacts and community perceptions of traditional forms of mining, such as coal and oil, have been well documented in a number of studies (Kitula, 2006; Tiwary, 2001; Garvin, McGee, Smoyer-Tomic \& Aubynn, 2009; Hossain, Gorman, Chapelle, Mann, Saal \& Penton, 2013). Additionally, the diverse economic, social and environmental impacts of mining are also well-established (Kitula, 2006). Some of these impacts include infrastructure development (Lockie, Franettovich, Petkova-Timmer, Rolfe \& Ivanova, 2009), employment and business opportunities (Buultjens, Brereton, Memmott, Reser, Thomson \& O’Rourke, 2010; Rolfe, Miles, Lockie \& Ivanova, 2007), environmental degradation (Dudka \& Adriano, 1997), and a lack of community cohesion (Petkova, Lockie, Rolfe \& Ivanova, 2009), among others. Mining has also impacted on policy, with policy implications and reform being central to mining changes and development (Banks, 2011).

Although the impacts of more traditional forms of mining have been established, CSG extraction is a relatively recent phenomenon in Australia. There are an increasing amount of studies exploring the impacts of CSG mining (Fleming \& Measham, 2015; Hossain et al., 2013). Nevertheless, the impacts are not well understood, with perceptions of affected communities an area that warrants further inquiry (Barrett, Couch, Metcalfe, Lytton, Adhikary \& Schmidt, 2013; Hamawand, Yusaf \& Hamawand, 2013; Lloyd, Luke \& Boyd, 2013). Consequently, the purpose of this research is to explore community perceptions of the impact of CSG extraction in Roma; a small rural town in South-West Queensland, Australia.

This research applies core concepts from social exchange theory and social representation theory to create a lens to view community perceptions of CSG mining in Roma. Developing an understanding of community perceptions of the impacts of CSG extraction has practical implications for policy and planning. For instance it can ensure the development of sustainable economies and resilient regions, where the impacts of CSG mining do not dictate community development or interfere with maintaining a diverse 
economy (Davoudi, Shaw, Haider, Quinlan, Peterson, Wilkinson, Funfgeld, McEvoy, Porter \& Davoudi, 2012; McLennan, Moyle \& Bec, 2015). This research also increases the conceptual understanding of CSG extraction which can provide the foundation for future management practices designed to enhance the positive aspects of CSG extraction, but also to mitigate the potential for negative impacts.

\section{Literature}

Change induced by economic activity is well-established within the literature, commonly discussed at the macro, meso and micro levels (Bec, McLennan \& Moyle, 2015). These changes are commonly expressed through impact studies with a number of economic sectors becoming the focus, including mining (Kitula, 2006), tourism (Mathieson \& Wall, 1982), forestry (Maeto \& Sato, 2004) and manufacturing (Holl, 2004). According to Kitula (2006), mining has become a focus of change studies as the industry tends to have a noticeable impact on the environment, economy and/or social systems. Literature in this area is extensive, with the impacts of mining well documented (Gilberthorpe \& Papyrakis, 2015; McDonald, Mayes, Pini, 2012).

Discussions surrounding the impacts of mining have gradually shifted over time. Impact studies originated from science disciplines and have gradually been adopted within the social sciences. For example, early research into the impacts of mining focused on the physical health and safety issues of mining activity (Fisher, 1944; Moss, 1923), as well as the environmental impacts on air, water and ecosystems (Bjerklie \& LaPerriere, 1985; Dougall, 1950; Lawrey, 1977). More recent studies have explored the link between the environmental impacts of mining and the subsequent health implications for the community and society more broadly (Smedley, Edmunds \& Pelig-Ba, 1996; Ballard \& Banks, 2003; Sengupta, 1993). In particular, the work by Thorton (1996) presented the impacts and implications of mining at a local scale, as well as nationally and globally. Thorton’s (1996) study identified 
that mining can have impacts across the triple bottom line (TBL), which includes the economy, society and the environment. This seminal work acknowledged the broader implications of mining for society as an inherently linked and complex system, and is critically important for developing appropriate strategies for development (Rogers \& Ryan, 2001). This initial perspective provided by Thornton (1996) gained substantial attention in the social sciences and generated an abundance of literature on the implications of mining for adjacent communities (Gibson \& Klinick, 2005; Jenkins, 2004; Labonne, 1999). Consequently, many of the impact assessments that occurred within local communities were predominantly associated with development, but were considered from a diverse range of geographical and mining contexts. For instance, Labonne (1999, pg. 315) highlighted the role mining plays within a community and the contribution it can make to community development, finding that the 'old school mining orthodoxy' is extinct, calling for mining companies to also embrace the social dimension.

Within discussions on the impacts of mining, there is a strong focus on the micro level change which results from mining activity. This change is often classified at the community level, where social, environmental and economic systems collide (Bec et al., 2015). As a result, exploring the community perceptions of mining induced change has become a popular theme in the literature. Community perceptions are also becoming a key focus of mining impact studies, as community members are increasingly having a greater role in development decision making (Prno \& Slocombe, 2012). Subsequently, extant literature has drawn on a number of different disciplinary perspectives to assess community perceptions of mining. Research in this area is commonly found within geography (Kemp, 2010; Petkova et al., 2009), environmental science (Kitula, 2006), sociology (Lockie et al., 2009), psychology (Petkova et al., 2009) and economics (Garvin et al., 2009). All the same, at a community 
level, the TBL (economic, environmental and sociocultural) has been central to discussions on the development of mining, particularly in regional communities (Rogers \& Ryan, 2001).

Despite studies considering the economic and social impact of mining (Ayree, 2001; Lockie et al., 2009), the majority of the research is focused on the impact of mining on the environment (Krook, Svensson \& Eklund, 2012). Kemp (2010) argues that the continued environmental focus has been detrimental to discussions on the impacts to society and the economy, and that there is a need for a more social science research to build theory that can be utilised to inform management action that drives change. Consequently, TBL impact studies underpinned by the notion of sustainability have become increasingly popular (Hilson \& Murck, 2000; Kitula, 2006; Veiga, Scoble \& McAllister, 2001). For instance, Hilson (2002) demonstrated how the impact of mining on land use was in turn impacting the local economy, leading to the demise of other sectors, such as agriculture. This created conflict and contention stemming from environments and reduced community cohesion (Hilson, 2002).

Likewise, Ballard and Banks (2003) explored the issue of resource conflict within communities, extending the impacts of mining to have social, economic and institutional implications for the region. Although the study focused on conflict and governance, the impacts of mining were acknowledged as a loss of a local community identity, loss of community rights and challenges to political regimes, among others. Additionally, a reduction in regulatory practices has compromised community values, shifting the control and power to mining companies and institutions supporting their practices (Ballard \& Banks, 2003).

Previous literature recognises that the impacts of mining are often spatially influenced, with differences by geographical context (Thorslund, Jarsjo, Chalov \& Belozerova, 2012). Consequently, the research in this field tends to be case study research considering different contexts (Everingham, Collins, Rifkin, Rodriguez, Baumgartl, Cavave 
\& Vink, 2014; Walton, McCrea, Leonard \& Williams, 2013).However, coal and heavy metal mining have predominantly been the focus throughout the studies (West, Charman, Grattan \& Cherburkin, 1997). Dudka and Adriano (1997) attribute this focus to the heightened health and environmental affects the extraction of coal in particular produces. Additionally, the focus on these minerals in the literature is also a reflection of the prominence of these types of mining, their widespread availability across various continents, driven by increasing global demand for these resources (Connolly \& Orsmond, 2010; Mudd, 2007, 2010).

On the other hand, Coal Seam Gas (CSG) is a relatively new fuel source which is becoming increasingly popular as an alternative energy source (Hamawand et al., 2013). The rapid expansion is attributed largely to advances in technology (Wang, Cheng, Ge, Chen, Li, Zhou \& Hai-Feng, 2013). Due to the rapid development of CSG technology, processes and systems, there is limited independent, empirically validated, publically available information relating to the impacts of CSG extraction. Research that has emerged tends to explore the surface impacts (Wagner \& Schumann, 1991), as well as other environmental impacts (Barrett et al., 2013; Hamawand et al., 2013).

Similar aspects of TBL have also emerged within discussion of GCS mining impacts. For example, social science studies have considered the social impacts of historical mining practices, presenting similar impacts of CSG to other forms of mining (de Rijke, 2013; Trigger et al., 2014). De Rijke (2013) found CSG extraction has the potential to generate a considerable impact on the social dynamics of the community, such as power shifts in governance and lifestyle changes. Other studies have considered the economic impacts of CSG extraction, particularly on other sectors such as agriculture (Chen \& Randall, 2013), as well as the impact of rapid and unconventional growth in the resources sector (Fleming \& Measham, 2015; Trigger et al., 2014). Uhlmann, Rifkin, Everingham, Head and May (2014) 
highlight the importance of socio-economic impact studies for the development of planning and policy processes, placing emphasis on the incorporation of community perceptions.

Like other forms of mining, community perceptions of CSG mining impacts have been recognised within a number of studies (Everingham et al., 2014; de Rijke, 2013; Measham \& Fleming, 2014; Walton et al., 2013; Williams \& Walton, 2013).Understanding how the community perceives mining is crucial to the role mining can play within a region (Moyle, McLennan, Becken \& Brown, 2014). Mining has been demonstrated to have implications for community development and the long-term sustainability of the industry in the region (Garvin et al., 2009; Idemudia, 2007). Studies have explored the community perceptions of mining based on the lived experiences of community members (Kitula, 2006). However, limited attention has been given to understand the changes themselves and how these changes influence community perceptions.

While studies often allude to meso and macro outcomes or impacts of mining, there remains a focus on impacts at the micro level. Researchers have drawn on a number of theories to not only aid in understanding the changes driven by mining, but also to explain the community perceptions of these changes (Moyle, Weiler \& Croy, 2013). However, before these theories can be explored, it is important to first understand the relationship between mining induced change and policy.

\subsection{Mining Induced Change and Policy}

When exploring micro level change induced by mining, discussions must also recognise the role of policy and legislation. It has been established that the impacts of mining on various community systems are greatly influenced by government policy, ultimately influencing regional development (Franks, Brereton \& Moran, 2010; Galloway, 2012). Evidently, regions often experience significant policy changes during times of mining growth and development (Franks et al., 2010). This can influence the degree to which a region is 
impacted. This can be because legislation is often designed to aid mining development and expansion, as well as being structured to enable the region to maximise mining's economic contribution (Banchirigah, 2006). Consequently in doing so, this can cause a number of impacts to emerge. Policy in this capacity, which commonly favours mining activity, has been discussed within the literature primarily from the perspective of the challenges it creates for the local community, such as zoning changes and an increase in power for mining companies often causing the resources sector to dictate regional development (Bebbington, Hinojosa, Humphreys, Bebbington, Burneo \& Warnaars, 2008; Hilson, 2002; Kitula, 2006). Additionally, communities and local businesses can often be restricted by policy in their ability to address the impacts of mining. For instance, Galloway (2012) identified policy and legislation changes to be impacting on the property rights of landowners. The study explored the invasion of mining companies on private land, the impact this was having on agricultural operations, and the lack of power landowners had to prevent these actions (Galloway, 2012). Unmistakeably, many regions have mining industry policy is in which encourages amicable relationships and support for communities (Kemp, 2010). A number of strategies have been implemented to aid in reducing the impacts of mining on the community. These strategies have been implemented at a government level, as well as an organisational level, such as Corporate Social Responsibility (CSR) and 'social license' policy (Kemp, 2010; Moffat \& Zhang, 2014; Prno \& Slocombe, 2012). However, there is significant contention in the literature to the level of regulation and enforcement over these policies, as well as the appropriateness of strategies to satisfy and align with community objectives (Hamann \& Kapelus, 2004; Jenkins, 2004; Mutti, Yakovleva, Vazquex-Brust \& Di Marco, 2012). Notwithstanding, further policy reform is needed to overcome the impacts communities are facing and balance the opposing beliefs of CSG mining (Mercer et al., 2014). Owen and 
Kemp (2013) emphasise that effective action must stem from regulated policy to ensure economic, social and environmental obligations are met.

Hamor (2004) highlights the need for greater consideration into policy restructuring for the extractive industries for two key reasons: to promote the sustainability of natural resources and reduce mineral exhaustion; and to ensure environmental and social systems are equally recognised, rather than being primarily economically focused. Currently there is inadequate discussion and research in to how policy is being or should be restructured to mitigate and manage the impacts of mining. Yet there is considerable positive movement, as a number of mining regions around the world are undergoing political reform, particularly to address environmental concerns associated with mining (Andrews-Speed, Zamora, Rogers, Shen, Cao \& Yang, 2002; Ashton, Love, Mahachi \& Dirks, 2001). Nevertheless, there are still substantial inadequacies with mining legislation, especially for regions continuing to experience development and expansion in mining activity. In particular, policy and legislative change to address community impacts from a social, economic and environmental perspective still warrant further attention. However, in order to inform appropriate policy reform, the theories which assist to understand the changes driven by mining and the community perceptions of these changes, must be explored.

\subsection{Theoretical Approaches to Research on Community Perceptions}

The factors which can influence an individual or group's perception of a specific economic sector or a controversial issue are widely discussed, particularly in psychology and sociology (Friedkin \& Johnsen, 1990; Oskamp \& Schultz, 2005). A number of theoretical approaches have been used to explore individual or collective perceptions of a particular phenomenon. Cultural theory and social identity theory are common heuristic devices used within the public perceptions literature (Devine-Wright, 2005; West et al., 2010). However, 
these two theories often portray an individual's position within a group and are not frequently used to portray collective public perceptions (Hogg, 2006).

More specifically, in an attempt to understand the changes that created or amplified by the mining industry and the community perceptions of these changes, studies have applied various theoretical perspectives and frameworks. These theories primarily stem from social change theories and include stakeholder theory, resilience theory and conflict theory. Stakeholder theory is a theory of organisational management, which addresses the structure and position of invested parties (Friedman \& Miles, 2002). Although not traditionally a theory of change, it has been increasingly applied in a change management context, as it has been used to explore the role and engagement of stakeholders in order to elicit or drive change (Ruf, Murdlidhar, Brown, Janney \& Paul, 2001). Within the context of mining induced change, Prno and Slocombe (2012) adopt stakeholder theory to examine how the shifts in policy and governance has largely aimed at improving its environmental and social performance, addressing common criticisms of micro level change for this sector.

Resilience theory is another change theory which has been used to understand mining impacts and the community response to these impacts (Bec et al., 2015). Resilience theory from this perspective is only a relatively new concept within the mining literature. However, it is gaining credibility as change management approach within the social sciences. Consequently, studies are beginning to emerge applying resilience theory to understand social constructs being affected by change. Gibson and Klinck’s (2005) study is one example of resilience theory being used to understand the social perspectives of the impacts of mining. In this study, the authors identify the relationship between the degree to which the community members were impacted by the changes driven my mining activity and their level of resilience (Gibson \& Klinck, 2005). On the other hand, conflict theory is perhaps the most commonly applied theory to understand community perceptions of mining induced change. 
Conflict, as a result of power challenges, is a key finding for many studies exploring the impacts of mining. Consequently, when interpreting the community perceptions of these impacts and associated changes, conflict theory is a commonly adopted approach to guide interpretations. The premise of conflict theory has been adopted by Ballard and Banks (2003) and de Rijke (2013), where community values are perceived to be compromised due to power shifts which were a result of growth within the mining industry.

A key limitation to the theories which have been used is that they tend to either focus on the cause/s of change or the outcomes of change, rather than understanding how these changes are perceived by the community. Two theories which are common within the public perception literature to understand perceptions of change, yet have not been applied within a mining context, include Social Representation Theory (SRT) and Social Exchange Theory (SET). Although SRT and SET have not been applied within this context, they have been effectively adopted by other disciplines, such as tourism, to explore similar change induced by an economic sector. Additionally, both SET and SRT are becoming more prominent within the change management literature (Anderson \& Anderson, 2014; Carter \& Beeton, 2008). Thus, SET and SRT will be adopted as a lens to view community perceptions of mining, to advance this body of literature and provide a different and more in-depth understanding of the associated changes.

Social Exchange Theory (SET) is a powerful tool that has been used to explore community perceptions of particularly contentious industries and associated development initiatives (Kayat, 2002). Grounded in sociology, social psychology and economics, SET conceptualizes the exchange of resources between individuals and groups in an interaction situation (Blau, 1964; Emerson, 1976; Homans, 1961). SET has gained considerable traction in studies seeking to explore community perceptions, as it is often used to develop a baseline measure of residents' perceptions to ascertain support for future development initiatives 
(Andereck, Valentine, Knopf, \& Vogt, 2005; McGehee \& Andereck, 2004). For instance, SET has long been recognised as an adequate theoretical base for exploring the community perceptions of tourism (Moyle, Croy, \& Weiler, 2010); a sector which has been identified as having a number of similar characteristics to mining (Miller, van Megen \& Buys, 2012). One of the core advantages of SET is that it has been described as a broad framework that other theories can operate, and thus is useful for examining large-scale social issues by way of investigating small-scale social situations (Stolte, Fine, \& Cook, 2001).

Social Representation Theory (SRT) is another core approach used to study how citizens construct and perceive societal and political issues (Hoijer, 2011). The basic premise of SRT is that individuals with similar attitudes or beliefs form clusters. SRT postulates relationships between individual perceptions and group the community according to key social representations (Fredline \& Faulkner, 2001). The literature on social representation provides a framework to explain how public perceptions are formed within a social context, where the individual or collective understanding is skewed by imposing factors. Perceptions are largely formed through experiences and how individuals are directly linked to specific impacts (Price, 1989). Third parties, such as the media, are also central to the formation of perceptions, particularly for individuals or groups who are not directly affected (Bickerstaff \& Walker, 2001; Callanan \& Rosenberger, 2011; Hoijer, 2011).

SRT has been extensively applied within attitudinal research (Moscardo, 2011). However, applications within a mining or resources sector context are relatively limited, though there are a couple of notable exceptions. Vojnovic, Michelson, Jackson and Bahn (2014) have applied SRT to understand the employee perceptions of FIFO operations, from which it was found that peer groups largely influenced individual attitudes of this form of employment. Furthermore, the notion of social representation within the context of mining has also been 
explored by McLennan, Becken and Moyle (2014); highlighting the role the media plays within the perceptions and social representation of mining and the resources sector.

Recently, Moyle et al. (2010) applied the process of SET, in combination with the salient representations of locals embedded within SRT, to explore the impacts of tourism on two Australian island communities. Building on this study, this research seeks to explore community perceptions of the impacts of CSG extraction in Roma, Australia. By merging key concepts embedded within each of these theoretical perspectives, this research makes a valuable contribution to the literature on community perceptions of mining. In particular, this research will generate rich theoretical insights into how community members perceive the impacts of a relatively new type of mining, which has experienced a rapid development and strong political support.

\section{Method}

\subsection{Case Study Region}

Located 515 kilometres west of Brisbane, Roma is a town located in the Maranoa region of Queensland, Australia. For a rural area, Roma has an economic base built primarily on the resources sector, agriculture and tourism. The region has had a long association with the resources sector, as it was the location where oil and gas was first discovered in Australia (Maranoa Regional Council, 2014). However, throughout history sustained gas production has been moderate, with agriculture being the dominant sector. This contributed to the formation of the rural country lifestyle within the community, predominantly situated around farming and livestock. Currently, mining is the largest contributor to the region's GDP, worth approximately \$240.6 million (Maranoa Regional Council, 2009). The rapid expansion of CSG has led to substantial infrastructure development and population growth (McLennan et 
al., 2015). However, limited research has explored the impacts of this CSG boom on the Roma community, particularly on its economic, social and environmental systems.

\subsection{Data collection and Analysis}

Research on community perceptions has taken a variety of methodological approaches (Guba \& Lincoln, 1994). Quantitative methods are the dominant approach in studies on community perceptions. This is particularly evident in studies which aim to measure and quantify impacts in order to inform government policy and decision making (Buys, Miller \& Van Megen, 2012). However, studies employing quantitative methods have been criticised for providing respondents with a predetermined list of attributes, rather than eliciting a social representation of the core issues that are at forefront of locals' minds (Moyle et al., 2010). Consequently there has been an emergence in qualitative methods, which complement existing quantitative research, by providing participants with an opportunity to elaborate indepth, and extract salient perceptions of core impacts (Foster, Burgos, Tejada, Caceres, Altamonte, Perez, Noboa, Urbaez, Heath, Hillard, Chiang \& Hall, 2010; Lloyd et al., 2013; Moffatt \& Pless-Mulloli, 2003). Given the limited knowledge that is available in relation to the impacts of CSG extraction, this research undertook an exploratory, qualitative approach to elicit individual perceptions (Kothari, 2004).

Grounded in the interpretative paradigm, this research undertook 40 semi-structured in-depth interviews with local residents and key stakeholders of the Roma region. Respondents were selected through a two tiered approach. Following a method by McLennan, Moyle, Ritchie and Ruhanen (2013), local residents of Roma were selected through a random sample of the White Pages Residential Directory, resulting in 200 residents contact details being obtained. Just over $15 \%$ of the residents contacted answered their telephone, with $90 \%$ agreeing to participate. In total, 27 resident interviews were conducted over the phone, ranging from 15 minutes to an hour. Connection to or involvement with the 
CSG mining activities was not required for participation, however it was evident that this was the case for a number participants. Purposive and snowball sampling was used to target key industry and government stakeholders in Roma, resulting in 13 face-to-face interviews that lasted about 45 to 60 minutes each. Key stakeholders included local government representatives, business owners, representatives from tourism and mining organisations, and representatives from community groups.

Both stakeholders and resident were asked similar questions, structured around topics such as demographics, place attachment, development of the region, perceptions of resources sector, and conflict and synergy between industries. Stakeholders were also asked more specific operational and strategic questions relating to Roma's economic development. Interviewing concluded once data saturation occurred. The point of data saturation is not dependent on a specific number of interviews. Rather, it is the point where no new themes, findings, concepts or problems are being elicited from the data (Creswell, 1994; Lamont., Kennelly \& Moyle, 2014). Interviews were transcribed and participants were assigned pseudonyms to preserve their anonymity. The transcripts were then coded for emergent concepts and themes using open, axial and selective coding in Microsoft Excel, with key quotes being collected in a word document throughout the coding process (Corbin \& Strauss, 1990).

\section{Results}

The results of this research unearth community perceptions of a diverse range of impacts of CSG mining on the economy, society and environment in Roma, with significant tension around key impacts. To explore these findings, the results are presented under key aspects of the TBL. However, the researchers acknowledge that many of these impacts are indeed interrelated and transcend the aforementioned classification. 


\subsection{Economic Impacts}

The economic impacts of CSG extraction identified by Roma respondents were clearly evident, and often perceived in a positive manner, especially related to increased business and employment opportunities: "You can see it has given a lot of younger people and older people opportunities” [Res_26]. Employment associated with CSG extraction was viewed as particularly beneficial: “It does provide a lot of employment..." [Res_2]. Stakeholders indirectly linked to mining also acknowledged that there were flow-on benefits from CSG extraction: “It's good for business because we supply Fluor and Santos and a lot of the mine drilling companies in the area..." [Stake_7]. The breadth of the flow-on impacts was further highlighted by another stakeholder, who claimed that: "engineering works are doing quite well... direct services are getting the major spin offs and are recouping a lot of money. Pubs are making a lot of money from guys coming in.” [Stake_6].

Another positive economic benefit highlighted by respondents was increased investment in the region. For example, CSG mining companies were identified as investing in local facilities, events and projects in the region: “...the gas companies put quite a bit of money into the town, backing cultural happenings" [Res_6]. The mining companies were identified as sponsoring regional events, which had assisted with the development of these events and enabled them to provide a greater economic contribution to the region. Community stakeholders noted an increase in the reputation and visitor numbers to the events since the mining companies had provided sponsorship: "Santos sponsors the Food and Fire Festival... it's pretty widely advertised now... it started out more of a local thing, but I think it's slowly picking up a bit of outside interest.” [Stake_10].

CSG was also inextricably linked to infrastructure development, particularly the development of the local airport which has had a number of economic impacts for the region, including making the region more accessible and affordable. Several respondents noted the cross pollination of the development of the airport to other important sectors, such as tourism: 
"There's real opportunity there to use that airport to service the whole of the region for a different type of tourism” [Stake_2]. The economic impact of the airport development also provides benefits to other businesses in Roma, by bringing an influx of passengers to the region: “we're going to put 250,000 passengers through the airport this year" [Stake_8].

Despite these positive economic impacts of the CSG boom, investment in the region by CSG companies was a source of contention among respondents. A key emergent theme amongst residents was the perception that the CSG companies' investments in the community were adequate, particularly as the community believed that minimal revenue remained in the region with a large FIFO population: "It's all very well to take all this money out of the area, but they're not really putting back as much as they should.” [Res_8]. Others noted the lack of local purchasing by the CSG companies: "They're not buying services in town unless they can't possibly avoid it. All the camps have container loads of things from Brisbane, so the butchers and supermarkets aren't making any money" [Stake_4]. In extreme cases respondents felt that the economic significance of the CSG sector to Roma was exaggerated or blatant propaganda: "When the gas moves out of here there will be a lot of houses empty, there will be a lot of roads buggered. They've done nothing really that great for Roma...." [Res_22].

Other economic impacts of the CSG boom identified by respondents included increased demand for employees, which had resulted in low unemployment within the region. However, this was considered both a positive and negative impact as it made it difficult for businesses not associated with the CSG boom to find and retain staff: “There's no unemployment in town because everybody's looking for staff. It's very hard to actually fill positions because everyone seems to go and join the mining industry” [Res_20]. Essentially this was reported to be a result of the ability of CSG companies were to offer higher remuneration packages: "they can get a job out on the rigs where they can earn two or three 
times as much money as what they would get as an apprentice” [Res_11]. Consequently, competition for labour had resulted in a number of small local businesses not directly associated with the resources sector closing down: "We had a small business in town that closed because of mining and the gas. Firstly, they took the workers, then they cranked all the rental properties up and it killed it. We've just closed it down...”[Res_22].

Respondents also identified that the CSG boom had negatively impacted other economic sectors in the region, particularly tourism and agriculture. Notably, the CSG boom had resulted in a policy shift within the local government, resulting in policies overly focused on the CSG sector, perceived to be to the detriment of other sectors. Consequently, the tourism sector had been impacted by accommodation constraints, increased costs and degraded infrastructure, such as roads. Other services in the region were also under pressure, including the local supermarkets, healthcare and education, a result of the high costs and lack of staff. Agriculture was also impacted, primarily by the impact of CSG extraction on prime agricultural land: “Some land holders aren't happy with the way the mining companies are leaving their properties when they leave them.” [Stake_9].

A key concern for residents, particularly those who were landowners, was that they did not have any rights regarding the decisions made about gas exploration and extraction on their land, nor did they feel that their opinions were adequately considered in the decision making process. Consequently, respondents felt that decisions were forced upon them: "...even though we have freehold land, we have no right to say no and that to me is a travesty of justice” [Res_7]. Another respondent noted, "I think those farmers who would prefer not to be involved don't really have that necessarily as an option and I don't think that's right" [Res_24].

Although some land owners indicated they had received compensation, often respondents did not feel this sufficiently addressed the interference and disruption to their 
lives and business: "You have to abide by their restrictions. You're not free to do whatever whenever; whereas they go onto people's lands and just do whatever they like and then don't return it to the way it was...” [Stake_3]. CSG extraction often resulted in landholders having to modify their operations: “...a lot of times there's water pondages happening, there's campsites on their land, there's roads being formed across their land and fences altered...” [Stake_6]. In addition, landowners indicated they were experiencing significant pressure from the mining companies: “...they don't let up on you until you sign. You know, they just put so much pressure on you” [Res_13]. Consequently, this caused emotional stress for some respondents: "You're nothing when they come to your place... It's damaged a lot of people on the land, and most people on the land today are over 55... they just can't handle it, it is dreadful.”[Res_13].

\subsection{Social Impacts}

Perhaps the most significant social impact identified by respondents was the erosion of the rural lifestyle. Both residents and stakeholders felt the CSG boom had changed Roma from a small country town to a busy and vibrant centre; an impact that was often discussed with dissatisfaction: "We've lost the small rural town environment. It's gone. It's now all about money and fast pace” [Res_12]. Respondents felt that the region's rapid change had significantly impacted on the atmosphere and character of the town, resulting in a decrease in community spirit and unity and loss of "the community feel that it used to have" [Stake_13]. This also was said to inhibit community cohesion, where new community members were regarded as 'outsiders' and considered to have separate objectives and values to the existing, long-standing community residents. Respondents also indicated that the CSG boom had created a transient population, with fly-in-fly-out workers: “The community spirit... it's gone. It's gone because the miners are here, they're on top dollar, they're in and out and why would they have community mind and spirit attached to them.” [Res_12]. 
The CSG boom had also increased local inflation, resulting in housing affordability challenges for locals. Displacement was a key social impact amongst community members, particularly for residents who were not employed by the resources sector. This was due to increased costs and a lack of accommodation: “...they've raised their rent... you can pay me $\$ 1500$ a week, when they used to charge $\$ 300$ a week" [Res_17]. This resulted in some people having to commute long distances to work in the town, with "some young people have moved out of Roma and moved 100 kilometres away and travel backwards and forwards every day to Roma because the rent's so dear..." [Res_11]. This also contributed to the lack of available skilled workers in the region: "teachers just could not afford to live here" [Res_24]. The increased cost of living and lack of affordable accommodation had resulted in an increased social polarisation within the region, where community segregation and inequality was a common outcome.

Community members noted that the CSG boom had rapidly increased the population in the region, which had been detrimental to residents as it had impacted on the quality of local infrastructure and services, such as roads healthcare and placed "stress on infrastructure...” [Res_2]. Noise pollution was also noted as an impact of the CSG boom, resulting from increase air and road traffic: "We don't live that far from the airport and the noise that's changed over the last umpteen years is pretty incredible” [Stake_8]. Respondents attributed these impacts to poor government planning: "The level of growth has been exponential to the point where local government as a planning body, has been playing catch up” [Stake_5]. However, there was evidence that the resources sector was also contributing to the redevelopment of the deteriorating roads and infrastructure: “...money that was being donated was being given by the mining companies for the express purpose to do the roads up" [Res_11]. Yet despite the efforts to maintain and fix the roads, there was "trouble keeping up with the problems of the roads" [Stake_9]. 
Regardless, some respondents perceived mining as had some positive social impacts for the region, with responses in this regard relating to increased vibrancy and a greater variety of retail and food outlets. However, further probing revealed this increased vibrancy often referred to "Subway, KFC, and McDonalds... they've been set up on the back of the vibrancy.” [Stake_9].

\subsection{Environmental Impacts}

The environmental impacts of CSG extraction were the cause of considerable concern and confusion for respondents, with water quality being the dominant concern. Respondents pointed out the role of CSG extraction in the contamination and depletion of underground water reserves, particularly the Great Artesian Basin. The Great Artesian Basin is important for Roma, as it is the region's only reliable water supply for domestic and stock watering requirements. Several respondents noted: “I'm very, very worried about the water... I don't think they know enough about what they do under the ground” [Res_13] and, “...the environmental side of things concerns me....fracking and things like that with our water table... there's not enough research into that.” [Res_24]. Respondents felt there was a lack of knowledge surrounding CSG extraction among the community, and desired more information about the environmental impacts of the activity: "A lot of people, and me included, are worried about the ground water and... the huge amounts of ground water that's coming from the town's supplies to support all the camps...” [Stake_8]. Some respondents also felt that if the concerns surrounding the environmental impacts, particularly the water supply, were alleviated then the impacts of CSG extraction on the community would be marginal: "I don't mind it. As long as they tick the boxes and safeguard us and convince our community that they're not impacting on the water" [Stake_2].

Furthermore, respondents indicated that CSG extraction can result in other associated issues, such as waste disposal and general litter. Waste was a key issue for the community: 
“there just seems to be litter everywhere” [Res_12], an impact attributed to the fly-in-fly-out miners: “...there's litter everywhere, Macca's papers thrown out of the mining vehicles” [Res_12]. Another respondent highlighted: “Our sewerage works and our rubbish tips are 300 per cent over capacity [Stake_6].

\section{Discussion}

Developing the resources sector is a common economic development strategy for many regional communities, especially in Australia (Eklund, 2015). However, if economic diversification is not maintained, the cyclical boom and bust nature of mining can result economic hardship when the boom ends (Miller et al., 2012). This research highlights the economic, social and environmental impacts of a CSG boom on Roma in Queensland, Australia. The strength of the recent CSG boom resulted in substantial positive economic contributions to the local economy and several key local infrastructure developments, such as the airport. Consequently, an emergent theme was respondents' inability to identify the economic benefits of CSG extraction for Roma, aligning with the impacts found in previous studies (Esteves, 2008; Lockie et al., 2009; Rolfe et al., 2007). Economic contribution and improved infrastructure are two factors that often influence government to deem an economic development strategy to be successful (Callois \& Aubert, 2007; Dixon, 1995). However, as identified by Callois \& Aubert (2007) measuring the success of economic development based on these narrow indicators is erroneous and does not consider the net impact on the region, particularly in terms of negative impacts such development might have on the community or environment.

Considering beyond the economic and infrastructure benefits of the CSG boom, this research found that the boom had a mixture of positive and negative impacts on the local community and environment. This finding connects with previous research suggesting that the positive economic impacts often overshadow negative economic, social and 
environmental impacts and result in support for an emerging sector and its associated development (Kitula, 2006; Lockie et al., 2009). Often, these negative impacts occur as the community is not sufficiently involved in the regional development and planning processes (Botes \& van Rensburg, 2000; Gertler \& Wolfe, 2004). Instead, the dominance and perceived importance of the mining companies influence or dictate the direction of the region's development (Botes \& van Rensburg, 2000; Garvin et al., 2009). By examining community perceptions through the lens of SRT, this research found that community members, particularly landowners, did not feel that they were a part of the decision making process. In fact, it was suggested that they were forced to yield to the objectives of the CSG companies. In a similar study, Buijs, Arts, Elands \& Lengkeek (2011) employed SRT to explore the conflict over Dutch woodland areas finding that community perceptions did not align with stakeholder strategies, resulting in community members feeling excluded from the decision making process. Therefore, by applying theories of social change to interpret the findings, it is possible to delve further in to the perception of respondents and expose deeper social and political issues stemming from economic activity (Hoijer, 2011).

Infrastructure development is important for rapidly expanding regions, as it enables the region to adequately cope with and manage change (Bunnell, Barter \& Morshidi, 2002; Ibem, 2009; Vorosmarty Green, Salisbury \& Lammers, 2000). However, Ibem (2009) argues that infrastructure development should focus on improving critical facilities and services for the community, such as sanitation and accommodation. Infrastructure development in Roma focused on improving access, through road and airport redevelopments, but failed to address deteriorating critical and services, such as health, education, supermarkets and waste and sewerage services.

Drawing from the exchange transaction between the two economic sectors in SET the social changes that have resulted from development, evidence from this research suggests 
that much of the infrastructure development in the region was specifically geared towards improving facilities that would enable CSG extraction or to offset the direct impacts of CSG activity. According to Emerson (1976), the lack of negotiation between parties can create conflict and heighten the negative perception of social change. In fact, was found that respondents felt that public infrastructure development had urbanised the region, which was not necessarily a desirable outcome for residents. Instead, respondents argued this had instead satisfied the needs of a new community of 'outsiders', rather than the existing community who were still attached to the rural lifestyle. This notion of developing for the 'outsider' community has been acknowledged within tourism studies, where development often occurs for the enjoyment or ease of tourists, rather than local residents (Bob \& Swart, 2009; Harrill, 2004). This is particularly evident for international sporting events, where tourist priorities are often placed before the local community objectives and intentions (Bob \& Swart, 2009). However, this is a relatively new perspective on development within the mining literature. Drawing from other fields, a more community centred approach to development is needed, recognising the transient community that exists and ensuring development caters to the longterm community residents (Bob \& Swart, 2009; Harrill, 2004).

Additionally, the CSG boom brought difficulties for local businesses, including labour shortages and increased rents. As remuneration is a key factor in a businesses' ability to attract and retain staff (Cable \& Judge, 1994), the CSG companies had a competitive advantage in the labour market due to their ability to pay high wages during the boom (Hutchings, De Cieri \& Shea, 2011), which impacted other sectors within the economy. This suggests allowing wages to grow unrestricted can result in significant impacts on a community. Previous research considering difficulties with the labour market in mining regions has focused on the need to reduce unemployment (Hutchings et al., 2011). There is previous research that suggests that high remuneration industries can significantly impact on 
other businesses in a region (Brock \& Evans, 1989; Porter, 2003); however, studies focused on the resources sector are limited. Available research within this area has largely been encompassed within discussions of the 'resource curse' or Dutch Disease (Bresser-Pereira, 2008; Sachs \& Warner, 2001). High remuneration is often considered to be a subset of inflation, with attention primarily given at a regional scale (van der Ploeg, 2011; van Wijnbergen, 1984). Yet the impact of wage disparity hasn't received substantial attention within the literature for resource-based communities. This research found that wage inequality is a key issue in Roma, resulting in flow-on impacts to other businesses and sectors, including their closure. Such wage disparities are very detrimental for regional labour markets, as some businesses can experience significant economic strain (Green, Dickerson \& Arbache, 2001; Topel, 1994) and reduce the quality and efficiency of business operations (Topel, 1994).

Respondents identified a clear link between local economic inflation and societal displacement. Inflation, particularly in the housing market, is a common societal impact within mining regions (Lockie et al., 2009; Petkova et al., 2009). This was further evidenced through the findings of this research, where the rising costs of living were impacting local residents, businesses, other sectors and visitors. In particular, tourism and agriculture were being constrained by the CSG boom, leading to a number of businesses closing or changing; a result of reduced profitability and resource constraints, particularly in terms of staff, land, water and infrastructure. The evidence of resource constraints in the region, support the hypothesis that there can be a 'resource curse', where economic growth and development is constrained by increased resources sector activity (Gilberthorpe \& Papyrakis, 2015; Mehlum, Moene \& Torvik, 2006). This process of crowding out other sectors is common in mining regions (Roberts \& McCosker, 2013). 
Previous research has found that the environmental impacts of mining are a core concern for communities (Garvin et al., 2009; Hilson, 2002; Veiga et al., 2001). This is associated with increased societal awareness and media focus on the environmental degradation the resources sector can reap (McLennan et al., 2014; Sampei \& Aoyagi-Usui, 2009). However, this was a key theme, other respondents in this study that did not place a strong emphasis on the environmental impacts of CSG extraction. This supports Kollmuss and Agyeman's (2002) findings that the action or reaction to environmental issues is often associated with being directly impacted by the change in environmental conditions and is strongly linked to how individuals perceive the impacts. The environmental degradation resulting from CSG extraction may not be evident to some community members as they are involved in the resources sector or are only new residents to the region (Kollmuss \& Agyeman, 2002; Price, 1989).

Additionally, residents did not feel they were well informed about the environmental impacts of CSG extraction and indicated they needed further information about the activity. This suggests that CSG extraction has occurred without due diligence being taken to understand and educate the community about its impact on the environment. This can be argued as one of the key aspects that intensifies the resistance and negative perceptions of CSG mining. Basu, Hicks, Krivokapic-Skolo and Sherley (2015) found that community engagement, open communication and timely responses to community concerns aided in overcoming the negative impacts or perceptions of mining in the region. Consequently in Roma, the lack of information has created an environment of concern and apprehension within the community that has created distrust for the resources sector. Respondents pointed out several environmental impacts they were concerned about. This included the degradation to water sources, air and soil, as well as increased waste and noise pollution. This follows the proposed environmental impacts of mining more traditional resources (Dudka \& Adriano, 
1997; Kitula, 2006), in addition to presenting similar impacts from studies utilising SET in tourism (Andereck et al., 2005; Ap, 1992).

The perceived impacts of CSG extraction in Roma on the social and economic systems were inextricably linked with the environmental impacts. Land use and its degradation were often at the centre of these impacts, highlighting that resource and land use can create significant conflict between sectors in a region and impact on a society (Hilson, 2002; Roberts \& McCosker, 2013). Using social change theories to understand the conflict, it was identified that land use was perhaps the dominant source of conflict in the region, with CSG extraction impeding on agricultural activity and interfering land ownership rights. This suggests that there were issues of equity apparent within the regions (Kayat, 2002). This follows Andereck et al. (2005) who used SET to understand the exchanges that must occur for economic growth within a community, often compromising environmental systems. Consequently it was proposed that increased land use planning and involvement of all stakeholders could substantially decrease the negative perceptions of CSG extraction (Andereck et al., 2005). Furthermore, previous studies have highlighted that increased community involvement and the adoption of Corporate Social Responsibility by mining companies can offset the negative impacts of mining and decrease community resistance to the activity (Basu et al., 2015; Hamann, 2004; Jenkins \& Yakovleva, 2006).

\section{Conclusion and Future Research}

This research explored the community perceptions of CSG extraction in Roma, revealing a wealth of interrelated positive and negative economic, social and environmental impacts for the community. This research found that the positive impacts of CSG extraction in Roma were short-term and overshadowed by the potential for long-term negative impacts. The findings revealed increased living costs were resulting in the displacement of community members not involved in the resources sector. Consequently, the CSG boom had not only 
outpriced many businesses in the labour market, but it had displaced many service sector employees who either moved from the region altogether or had to travel long distances to work in Roma each day. Other economic sectors, such as tourism and agriculture, were also negatively impacted by resource conflict with the CSG sector.

However, the prominent concern was the development of infrastructure and how it impeded regional development. Previous research suggests that mining companies can contribute significantly to a region through infrastructure development (Basu, et al., 2015; Lockie et al., 2009; Pegg, 2006). However, this research suggests that the development of infrastructure in Roma was predominantly for the benefit of the mining companies to support further CSG extraction. In fact, the influx of new people to the region had strained many critical services, such as roads, health, education, waste and sewerage. Several residents felt that the economic and infrastructure development that had occurred had been detrimental to the region, as it had resulted in the rural atmosphere of the region changing. Combining key concepts from SRT and SET has enabled an elicitation of residents' salient perceptions of CSG. This research was able to gain a social representation of an exchange between the community and the mining sector, which has not previously been obtained in a mining context.

This research contributes an understanding of the community perceptions of the impacts of CSG extraction, which can inform regional development and CSR initiatives. By exploring the impacts of CSG extraction across the TBL, a theoretically driven understanding of the community perceptions of the impacts of CSG extraction has been developed. This research was undertaken in a region that has recently experienced significant structural change as a result of a CSG boom. Consequently, the intensity of some impacts are stronger with some residents (e.g. those who have lived in the region for a long time), but may not be evident to other residents (e.g. those who have just moved to the region or are involved in the 
resources sector). Thus, further research should explore the community perceptions of CSG extraction within a region that has a well-established and stable CSG sector. Further research could also explore strategies for offsetting the negative impacts of CSG extraction, including tools the community can employ to better manage and build resilience to the negative impacts of the activity. However; a limitation of this research is that findings are not representative of the perceptions of the entire community. This needs to be considered when undertaking future research to explore potential strategies for the community. Additionally, investigation is also needed to explore the economic strategies to reduce the wage disparity, such as capping wages. 


\section{References}

Andereck, K. L., Valentine, K. M., Knopf, R. C., \& Vogt, C. A. (2005). Residents' perceptions of community tourism impacts. Annals of Tourism Research, 32(4), 10561076.

Andersén, J., \& Andersén, A. (2014). Deconstructing resistance to organizational change: A social representation theory approach. International Journal of Organizational Analysis, 22(3), 342-355.

Andrews-Speed, P., Zamora, A., Rogers, C. D., Shen, L., Cao, S., \& Yang, M. (2002). A framework for policy formulation for small-scale mines: the case of coal in China. Natural Resources Forum, 26(1), 45-54.

Ap, J. (1992). Residents' perceptions on tourism impacts. Annals of Tourism Research, 19(4), 665-690.

Ashton, P., Love, D., Mahachi, H., and Dirks, P. (2001). An Overview of the Impact of Mining and Mineral Processing Operations on Water Resources and Water Quality in the Zambezi, Limpopo and Olifants Catchments in Southern Africa. A report prepared for the Mining, Minerals and Sustainable Development, Southern Africa. CSIREnvironmentek, Pretoria, South Africa and Geology Department, University of Zimbabwe, Harare, Zimbabwe. Report No. ENV-P-C 2001-04.

Ballard, C., \& Banks, G. (2003). Resource wars: The anthropology of mining. Annual Review of Anthropology, 32, 287-313.

Banchirigah, S. M. (2006). How have reforms fuelled the expansion of artisanal mining? Evidence from sub-Saharan Africa. Resources Policy, 31(3), 165-171.

Banks, G. (2011). Australia's mining boom: What's the problem?. Address to the Melbourne Institute and The Australian Economic and Social Outlook Conference, Melbourne, 30 June.

Barrett, D. J., Couch, C. A., Metcalfe, D. J., Lytton, L., Adhikary, D. P., \& Schmidt, R. K. (2013). Methodology for bioregional assessments of the impacts of coal seam gas and coal mining development on water resources. A report prepared for the Independent Expert Scientific Committee (IESC) on Coal Seam Gas and Large Coal Mining Development through the Department of Sustainability, Environment, Water, Population and Communities (SEWPaC).

Basu, P. K., Hicks, J., Krivokapic-Skolo, B., \& Sherley, C. (2015). Mining operations and corporate social responsibility: A case of a large gold mine in regional Australia. The Extractive Industries and Society, 2(3), 531-539.

Bebbington, A., Hinojosa, L., Humphreys Bebbington, D., Burneo, M. L., \& Warnaars, X. (2008). Contention and ambiguity: Mining and the possibilities of development. Development and Change, 39(6), 887-914.

Bec, A., McLennan, C., \& Moyle, B. (2015). Community resilience to long-term tourism decline and rejuvenation: A literature review and conceptual model. Current Issues in Tourism, pp. 1-27.

Bickerstaff, K., \& Walker, G. (2001). Public understandings of air pollution: the 'localisation' of environmental risk. Global Environmental Change, 11(2), 133-145.

Bjerklie, D. M., \& LaPerriere, J. D. (1985). Gold-mining effects on stream hydrology and water quality, circle quadrangle, Alaska. Journal of the American Water Resources Association, 21(2), 235-242.

Blainey, G. (1993). The rush that never ended: A history of Australian mining (5 ed.). Carlton: Melbourne University Press.

Blau, P. M. (1964). Exchange and power in social life. New York: Wiley. 
Bob, U., \& Swart, K. (2009). Resident Perceptions of the 2010 FIFA Soccer World Cup Stadia Development in Cape Town. Urban Forum, 20(1), 47-59.

Botes, L., \& van Rensburg, D. (2000). Community participation in development: nine plagues and twelve commandments. Community Development Journal, 35(1), 41-58.

Bresser-Pereira, L. C. (2008). The Dutch disease and its neutralization: a Ricardian approach. Revista de Economia Política, 28(1), 47-71.

Brock, W. A., \& Evans, D. S. (1989). Small business economics. Small Business Economics, 1(1), 7-20.

Buijs, A. E., Arts, B. J. M., Elands, B. H. M., \& Lengkeek, J. (2011). Beyond environmental frames: The social representation and cultural resonance of nature in conflicts over a Dutch woodland. Geoforum, 42(3), 329-341.

Bunnell, T., Barter, P. A., \& Morshidi, S. (2002). Kuala Lumpur metropolitan area: A globalizing city-region. Cities, 19(5), 357-370.

Buultjens, J., Brereton, D., Memmott, P., Reser, J., Thomson, L., \& O'Rourke, T. (2010). The mining sector and indigenous tourism development in Weipa, Queensland. Tourism Management, 31(5), 597-606.

Buys, L., Miller, E., \& van Megen, K. (2012). Conceptualising climate change in rural Australia: community perceptions, attitudes and (in) actions. Regional Environmental Change, 12(1), 237-248.

Cable, D. M., \& Judge, T. A. (1994). Pay preferences and job search decisions: A personorganization fit perspective. Personnel Psychology, 47(2), 317-348.

Callanan, V. J., \& Rosenberger, J. S. (2011). Media and public perceptions of the police: examining the impact of race and personal experience. Policing and Society, 21(2), 167-189.

Callois, J.-M., \& Aubert, F. (2007). Towards indicators of social capital for regional development issues: The case of French rural areas. Regional Studies, 41(6), 809-821.

Carter, R. W., \& Beeton, R. J. S. (2008). Managing cultural change and tourism: A review and perspective. In B. Prideaux, D. Timothy \& K. Chon (Eds.), Cultural and heritage tourism in Asia and the Pacific (pp. 134-156). New York: Routledge.

Chen, C., \& Randall, A. (2013). The economic contest between coal seam gas mining and agriculture on prime farmland: It may be closer than we thought. Journal of Economic and Social Policy, 15(3).

Connolly, E., \& Orsmond. (2010). The Mining Industry: From Bust to Boom. Paper presented at the Reserve Bank of Australia Conference: The Australian Economy in the 2000s, Sydney.

Corbin, A., \& Strauss, J. M. (1990). Basics of qualitative research: Grounded theory procedures and techniques. Thousand Oaks: Sage.

Creswell, J. W. (1994). Research design: Qualitative and quantitative approach. Thousand Oaks: Sage.

Davoudi, S., Shaw, K., Haider, L. J., Quinlan, A. E., Peterson, G. D., Wilkinson, C., Funfgeld, H., McEvoy, D., Porter, L., \& Davoudi, S. (2012). Resilience: A Bridging Concept or a Dead End? "Reframing” Resilience: Challenges for Planning Theory and Practice Interacting Traps: Resilience Assessment of a Pasture Management System in Northern Afghanistan Urban Resilience: What Does it Mean in Planning Practice? Resilience as a Useful Concept for Climate Change Adaptation? The Politics of Resilience for Planning: A Cautionary Note. Planning Theory \& Practice, 13(2), 299-333.

de Rijke, K. (2013). Coal seam gas and social impact assessment: An anthropological contribution to current debates and practices. Journal of Economic and Social Policy, 15(3) 
Devine-Wright, P. (2005). Beyond NIMBYism: towards an integrated framework for understanding public perceptions of wind energy. Wind Energy, 8(2), 125-139.

Dixon, J. (1995). Community stories and indicators for evaluating community development. Community Development Journal, 30(4), 327-336.

Dougall, B. M. (1950). The effects of open-cast coal mining on agricultural land. Journal of the Science of Food and Agriculture, 1(8), 225-229.

Dudka, S., \& Adriano, D. C. (1997). Environmental impacts of metal ore mining and processing: A review. Journal of Environmental Quality, 26(3), 590-602.

Eklund, E. (2015). Mining in Australia: An historical survey of industry-community relationships. The Extractive Industries and Society, 2(1), 177-188.

Eklund, E. (2012). Mining towns: Making a living, making a life. Kensington: University of New South Wales Press.

Emerson, R. M. (1976). Social Exchange Theory. Annual Review of Sociology, 2, 335-362.

Esteves, A. M. (2008). Evaluating community investments in the mining sector using multicriteria decision analysis to integrate SIA with business planning. Environmental Impact Assessment Review, 28(4-5), 338-348.

Everingham, J.-A., Collins, N., Rifkin, W., Rodriguez, D., Baumgartl, T., Cavaye, J., \& Vink, S. (2014). How farmers, graziers, miners, and gas-industry personnel see their potential for coexistence in rural Queensland. Society of Petroleum Engineers Economics \& Management Journal, 6(3), 122-130.

Fisher, S. W. (1944). Health hazards of coal-mining. British Journal of Industrial Medicine, 1(3), 153-158.

Fleming, D. A., \& Measham, T. G. (2015). Local economic impacts of an unconventional energy boom: The coal seam gas industry in Australia. Australian Journal of Agricultural and Resource Economics, 59(1), 78-94.

Foster, J., Burgos, R., Tejada, C., Cáceres, R., Altamonte, A. T., Perez, L. J., .Noboa, F., Urbaez, M. F., Heath, A., Hilliard, R. C., Chiang, F., \& Hall, P. (2010). A community-based participatory research approach to explore community perceptions of the quality of maternal-newborn health services in the Dominican Republic. Midwifery, 26(5), 504-511.

Franks, D. M., Brereton, D., \& Moran, C. J. (2010). Managing the cumulative impacts of coal mining on regional communities and environments in Australia. Impact Assessment and Project Appraisal, 28(4), 299-312.

Fredline, E., \& Faulkner, B. (2001). Variations in residents' reactions to major motorsport events: Why residents perceive the impacts of events differently. Event Management, $7(2), 115-125$.

Friedkin, N. E., \& Johnsen, E. C. (1990). Social influence and opinions. The Journal of Mathematical Sociology, 15(3-4), 193-206.

Friedman, A. L., \& Miles, S. (2002). Developing stakeholder theory. Journal of Management Studies, 39(1), 1-21.

Galloway, K. (2012). Landowners' vs miners' property interests: The unsustainability of property as dominion. Alternative Law Journal, 37(2), 77-81.

Garvin, T., McGee, T. K., Smoyer-Tomic, K. E., \& Aubynn, E. A. (2009). Communitycompany relations in gold mining in Ghana. Journal of Environmental Management, 90(1), 571-586.

Gertler, M. S., \& Wolfe, D. A. (2004). Local social knowledge management: Community actors, institutions and multilevel governance in regional foresight exercises. Futures, 36(1), 45-65. 
Gibson, G., \& Klinick, J. (2005). Canada’s resilient north: The impact of mining on aboriginal communities. A Journal of Aboriginal and Indigenous Community Health, 3(1), 115-139.

Gilberthorpe, E., \& Papyrakis, E. (2015). The extractive industries and development: The resource curse at the micro, meso and macro levels. The Extractive Industries and Society, 2(2), 381-390.

Green, F., Dickerson, A., \& Arbache, S. J. (2001). A picture of wage inequality and the allocation of labor through a period of trade liberalization: The case of Brazil. World Development, 29(11), 1923-1939.

Guba, E. G., \& Lincoln, Y. S. (1994). Competing paradigms in qualitative research. Handbook of qualitative research, 2(163-194).

Hamann, R. (2004). Corporate social responsibility, partnerships, and institutional change: The case of mining companies in South Africa. Natural Resources Forum, 28(4), 278290.

Hamawand, I., Yusaf, T., \& Hamawand, S. G. (2013). Coal seam gas and associated water: A review paper. Renewable and Sustainable Energy Reviews, 22(0), 550-560.

Hámor, T. (2004). Sustainable mining in the European Union: The legislative aspect. Environmental Management, 33(2), 252-261.

Harrill, R. (2004). Residents' attitudes toward tourism development: A literature review with implications for tourism planning. Journal of Planning Literature, 18(3), 251-266.

Hilson, G. (2002). An overview of land use conflicts in mining communities. Land Use Policy, 19(1), 65-73.

Hilson, G., \& Murck, B. (2000). Sustainable development in the mining industry: clarifying the corporate perspective. Resources Policy, 26(4), 227-238.

Hogg, M. A. (2006). Social Identity Theory. In P. J. Burke (Ed.), Contemporary social psychological theories (pp. 111-136). California Stanford University Press.

Hoijer, B. (2011). Social representations theory. Nordicom Review, 32(2), 3-16.

Holl, A. (2004). Manufacturing location and impacts of road transport infrastructure: empirical evidence from Spain. Regional Science and Urban Economics, 34(3), 341363.

Homans, G. C. (1961). Social behavior: Its elementary forms. New York: Harcourt, Brace \& World.

Hossain, D., Gorman, D., Chapelle, B., Mann, W., Saal, R., \& Penton, G. (2013). Impact of the mining industry on the mental health of landholders and rural communities in southwest Queensland. Australasian Psychiatry, 21(1), 32-37.

Hutchings, K., De Cieri, H., \& Shea, T. (2011). Employee attraction and retention in the australian resources sector. Journal of Industrial Relations, 53(1), 83-101.

Ibem, E. O. (2009). Community-led infrastructure provision in low-income urban communities in developing countries: A study on Ohafia, Nigeria. Cities, 26(3), 125132.

Idemudia, U. (2007). Community perceptions and expectations: Reinventing the wheels of corporate social responsibility practices in the Nigerian oil industry. Business and Society Review, 112(3), 369-405.

Jenkins, H. (2004). Corporate social responsibility and the mining industry: Conflicts and constructs. Corporate Social Responsibility and Environmental Management, 11(1), 23-34. 
Jenkins, H. M., \& Yakovleva, N. (2006). Corporate social responsibility in the mining industry: exploring trends in social and environmental disclosure. Journal of Cleaner Production, 14(3-4), 271-284.

Kayat, K. (2002). Power, social exchanges and tourism in Langkawi: rethinking resident perceptions. International Journal of Tourism Research, 4(3), 171-191.

Kemp, D. (2010). Mining and community development: Problems and possibilities of locallevel practice. Community Development Journal, 45(2), 198-218.

Kitula, A. G. N. (2006). The environmental and socio-economic impacts of mining on local livelihoods in Tanzania: A case study of Geita District. Journal of Cleaner Production, 14(3-4), 405-414.

Kollmuss, A., \& Agyeman, J. (2002). Mind the Gap: Why do people act environmentally and what are the barriers to pro-environmental behavior? Environmental Education Research, 8(3), 239-260.

Kothari, C. R. (2004). Research methodology: methods and techniques ( $2^{\text {nd }}$ ed.). Delhi: New Age.

Krook, J., Svensson, N., \& Eklund, M. (2012). Landfill mining: A critical review of two decades of research.Waste management,32(3), 513-520.

Labonne, B. (1999). The mining industry and the community: Joining forces for sustainable social development. Natural Resources Forum, 23(4), 315-322.Lamont, M., Kennelly, M., Moyle, B. D. (2014). Costs and Perseverance in Serious Leisure Careers, Leisure Sciences, 36(2), 144-160.

Lawrence, S., \& Davies, P. (2011). An archaeology of Australia since 1788. New York: Springer.

Lawrey, J. D. (1977). The relative decomposition potential of habitats variously affected by surface coal mining. Canadian Journal of Botany, 55(11), 1544-1552.

Lin, W., Zhang, N., \& Gu, A. (2010). LNG (liquefied natural gas): A necessary part in China's future energy infrastructure. Energy, 35(11), 4383-4391.

Lloyd, D. J., Luke, H., \& Boyd, W. E. (2013). Community perspectives of natural resource extraction: coal-seam gas mining and social identity in Eastern Australia. Coolabah, 10, 144-164.

Lockie, S., Franettovich, M., Petkova-Timmer, V., Rolfe, J., \& Ivanova, G. (2009). Coal mining and the resource community cycle: A longitudinal assessment of the social impacts of the Coppabella coal mine. Environmental Impact Assessment Review, 29(5), 330-339.

Maeto, K., \& Sato, S. (2004). Impacts of forestry on ant species richness and composition in warm-temperate forests of Japan. Forest Ecology and Management, 187(2-3), 213223.

Maranoa Regional Council. (2014). Business and industry in the region. Retrieved June 23, from http://www.maranoa.qld.gov.au/business-and-industry-in-the-region

Maranoa Regional Council. (2009). Maranoa Regional Economic Development Strategy Background. Retrieved from http://www.maranoa.qld.gov.au/c/document_library/get_file?uuid=996b3f5a-7cb840ac-a277-a63fa7239d7f\&groupId=4292453

Mathieson, A., \& Wall, G. (1982). Tourism, economic, physical and social impacts. London: Longman.

McDonald, P., Mayes, R., \& Pini, B. (2012). Mining work, family and community: A spatially-oriented approach to the impact of the Ravensthorpe nickel mine closure in remote Australia. Journal of Industrial Relations, 54(1), 22-40

McGehee, N. G., \& Andereck, K. L. (2004). Factors predicting rural residents' support of tourism. Journal of Travel Research, 43(2), 131-140. 
McLennan, C. J., Becken, S., \& Moyle, B. D. (2014). Framing in a contested space: media reporting on tourism and mining in Australia. Current Issues in Tourism, 1-21.

McLennan, C. I, Moyle, B. D, \& Bec, A. (2015) Overcoming Structural Lock-In: Strategies for enhancing the co-existence between tourism and the resources sector. Griffith Institute for Tourism Research Report Series, Report No 4, Griffith University, Gold Coast, Australia

McLennan, C. J., Moyle, B. D., Ritchie, B. W. \& Ruhanen, L. M. (2013). Developing and Testing a Suite of Institutional Indices to Underpin the Measurement and Management of Tourism Destination Transformation, Tourism Analysis, 18(2), 157171.

Measham, T. G., \& Fleming, D. A. (2014). Impacts of unconventional gas development on rural community decline. Journal of Rural Studies, 36, 376-385.

Mercer, A., de Rijke, K., \& Dressler, W. (2014). Silences in the boom: coal seam gas, neoliberalizing discourse, and the future of regional Australia. Journal of Political Ecology, 21, 279-302.

Mehlum, H., Moene, K., \& Torvik, R. (2006). Institutions and the Resource Curse. The Economic Journal, 116(508), 1-20.

Miller, E., van Megen, K., \& Buys, L. (2012). Diversification for sustainable development in rural and regional Australia: How local community leaders conceptualise the impacts and opportunities from agriculture, tourism and mining. Rural Society, 22(1), 2-16.

Minifie, J., Cherastidtham, I., Mullerworth, D., \& Savage, J. (2013). The mining boom: Impacts and prospects: Grattan Institute

Moffat, K., \& Zhang, A. (2014). The paths to social licence to operate: An integrative model explaining community acceptance of mining. Resources Policy, 39, 61-70.

Moffatt, S., \& Pless-Mulloli, T. (2003). “It wasn’t the plague we expected.” Parents’ perceptions of the health and environmental impact of opencast coal mining. Social Science \& Medicine, 57(3), 437-451.

Moscardo, G. (2011). Exploring social representations of tourism planning: issues for governance. Journal of Sustainable Tourism, 19(4-5), 423-436.

Moss, K. N. (1923). Some effects of high air temperatures and muscular exertion upon colliers. Proceedings of the Royal Society of London, 95(666), 181-200.

Moyle, B. D., Croy W. G. \& Weiler, B. (2010). Community Perceptions of Tourism: Bruny and Magnetic Islands, Australia, Asia Pacific Journal of Tourism Research, 15(3), 353-366

Moyle, B. D., McLennan, C. Becken, S. \& Brown, R. (2014). Learning to Play Nice: Conflict, Synergy and Strategies for Co-Existence between Tourism and the Resource Sector. Paper presented at CAUTHE 2014 "Tourism and Hospitality in the Contemporary World: Trends, Changes and Complexity” (10th-13th of February 2014), Brisbane, Australia.

Moyle, B. D., Weiler, B. \& Croy W. G. (2013). Visitors' Perceptions of Tourism Impacts on Bruny and Magnetic Islands, Australia, Journal of Travel Research, 52(3), 392-406.

Mudd, G. M. (2007). Global trends in gold mining: Towards quantifying environmental and resource sustainability. Resources Policy, 32(1-2), 42-56.

Mudd, G. M. (2010). The environmental sustainability of mining in Australia: key megatrends and looming constraints. Resources Policy, 35(2), 98-115.

Mutti, D., Yakovleva, N., Vazquez-Brust, D., \& Di Marco, M. H. (2012). Corporate social responsibility in the mining industry: Perspectives from stakeholder groups in Argentina. Resources Policy, 37(2), 212-222. 
Nghiem, L. D., Ren, T., Aziz, N., Porter, I., \& Regmi, G. (2011). Treatment of coal seam gas produced water for beneficial use in Australia: A review of best practices. Desalination and Water Treatment, 32(1-3), 316-323.

Oskamp, S., \& Schultz, P. W. (2005). Attitudes and Opinions (3 ed.). New Jersey: Lawrence Erlbaum Associates.

Owen, J. R., \& Kemp, D. (2013). Social licence and mining: A critical perspective. Resources Policy, 38(1), 29-35.

Pegg, S. (2006). Mining and poverty reduction: Transforming rhetoric into reality. Journal of Cleaner Production, 14(3-4), 376-387.

Pellegrino, C., \& Lodhia, S. (2012). Climate change accounting and the Australian mining industry: exploring the links between corporate disclosure and the generation of legitimacy. Journal of Cleaner Production, 36(0), 68-82.

Petkova, V., Lockie, S., Rolfe, J., \& Ivanova, G. (2009). Mining developments and social impacts on communities: Bowen Basin case study. Rural Society, 19(3), 211-228.

Petrova, S., \& Marinova, D. (2014). Using 'soft'and 'hard'social impact indicators to understand societal change caused by mining: a Western Australia case study. Impact Assessment and Project Appraisal, (ahead-of-print), 1-12

Porter, M. (2003). The economic performance of regions. Regional Studies, 37(6-7), 545-546.

Price, V. (1989). Social identification and public opinion: Effects of communicating group conflict. Public Opinion Quarterly, 53(2), 197-224.

Prno, J., \& Slocombe, D. S. (2012). Exploring the origins of 'social license to operate' in the mining sector: Perspectives from governance and sustainability theories. Resources Policy, 37(3), 346-357.

Ruf, B. M., Muralidhar, K., Brown, R. M., Janney, J. J., \& Paul, K. (2001). An empirical investigation of the relationship between change in corporate social performance and financial performance: A stakeholder theory perspective. Journal of Business Ethics, 32(2), 143-156.

Roberts, A., \& McCosker, A. (2013, July 25). Regions warned mining 'crowds out' agriculture, $A B C$ Capricornia. Retrieved from http://www.abc.net.au/local/stories/2013/07/25/3810746.htm

Rogers, M., \& Ryan, R. (2001). The triple bottom line for sustainable community development. Local Environment, 6(3), 279-289.

Rolfe, J., Miles, B., Lockie, S., \& Ivanova, G. (2007). Lessons from the social and economic impacts of the mining boom in the Bowen basin 2004-2006. Australasian Journal of Regional Studies, 13(2), 134-153.

Sachs, J. D., \& Warner, A. M. (2001). The curse of natural resources. European Economic Review, 45(4-6), 827-838.

Sampei, Y., \& Aoyagi-Usui, M. (2009). Mass-media coverage, its influence on public awareness of climate-change issues, and implications for Japan's national campaign to reduce greenhouse gas emissions. Global Environmental Change, 19(2), 203-212.

Sengupta, M. (1993). Environmental impacts of mining: Monitoring, restoration, and control. Boca Raton, Florida: Lewis Publishers.

Smedley, P. L., Edmunds, W. M., \& Pelig-Ba, K. B. (1996). Mobility of arsenic in groundwater in the Obuasi gold-mining area of Ghana: some implications for human health. Geological Society, London, Special Publications, 113(1), 163-181.

Stolte, J. F., Fine, G. A., \& Cook, K. S. (2001). Sociological miniaturism: Seeing the big through the small in social psychology. Annual Review of Sociology, 27, 387-413.

Thorslund, J., Jarsjö, J., Chalov, S. R., \& Belozerova, E. V. (2012). Gold mining impact on riverine heavy metal transport in a sparsely monitored region: the upper Lake Baikal Basin case. Journal of Environmental Monitoring, 14(10), 2780-2792. 
Thorton, I. (1996). Impacts of mining on the environment; some local, regional and global issues. Applied geochemistry, 11, 355-361.

Tiwary, R. K. (2001). Environmental impact of coal mining on water regime and its management. Water, Air, and Soil Pollution, 132(1-2), 185-199.

Tomaney, J. (2010). Place-based approaches to regional development: Global trends and Australian implications. Sydney: Australian Business Foundation Limited.

Topel, R. H. (1994). Regional labor markets and the determinants of wage inequality. The American Economic Review, 84(2), 17-22.

Trigger, D., Keenan, J., de Rijke, K., \& Rifkin, W. (2014). Aboriginal engagement and agreement-making with a rapidly developing resource industry: Coal seam gas development in Australia. The Extractive Industries and Society, 1, 176-188.

Uhlmann, V., Rifkin, W., Everingham, J., Head, B., \& May, K. (2014). Prioritising indicators of cumulative socio-economic impacts to characterise rapid development of onshore gas resources. The Extractive Industries and Society, 1(2), 189-199.

van der Ploeg, F. (2011). Natural Resources: Curse or Blessing? Journal of Economic Literature, 49(2), 366-420.

van Wijnbergen, S. (1984). Inflation, employment, and the Dutch Disease in oil-exporting countries: A short-run disequilibrium analysis. The Quarterly Journal of Economics, 99(2), 233-250.

Veiga, M. M., Scoble, M., \& McAllister, M. L. (2001). Mining with communities. Natural Resources Forum, 25(3), 191-202.

Vojnovic, P., Michelson, G., Jackson, D., \& Bahn, S. (2014). Adjustment, well-being and help-seeking among Australian FIFO mining employees. Australian Bulletin of Labour, 40(2), 242-261.

Vörösmarty, C. J., Green, P., Salisbury, J., \& Lammers, R. B. (2000). Global water resources: Vulnerability from climate change and population growth. Science, 289(5477), 284288.

Walton, A. M., McCrea, R., Leonard, R., \& Williams, R. (2013). Resilience in a changing community landscape of coal seam gas: Chinchilla in southern Queensland. Journal of Economic and Social Policy, 15(3), 4-28.

Wang, L., Cheng, Y. P., Ge, C. G., Chen, J. X., Li, W., Zhou, H. X., \& Hai-Feng, W. (2013). Safety technologies for the excavation of coal and gas outburst-prone coal seams in deep shafts. International Journal of Rock Mechanics and Mining Sciences, 57, 2433.

Wagner, H., \& Schumann, E. H. R. (1991). Surface effects of total coal-seam extraction by underground mining methods. Journal of the South African Institute of Mining and Metallurgy, 91(7), 221-231.

West, S., Charman, D. J., Grattan, J. P., \& Cherburkin, A. K. (1997). Heavy metals in holocene peats from south west England: Detecting mining impacts and atmospheric pollution. Water, Air \& Soil Pollution, 100, 343-353.

Williams, R., \& Walton, A. M. (2013). The social licence to operate and coal seam gas development. A literature review report to the Gas Industry Social and Environmental Research Alliance (GISERA). CSIRO: Canberra. 